\title{
BİNGÖL'DE AVCILIK GELENEĞİ VE AVCI FIKRALARI
}

\author{
Ömer Faruk ELALTUNTAȘ
}

\begin{abstract}
Özet
Halk edebiyatı, milletimizin yüzyıllar boyu süregelen kültür hazinesidir. Bu engin hazine içerisinde destanlardan efsanelere, masallardan halk hikâyelerine kadar birçok sözlü kültür unsuruna rastlamak mümkündür. Bu unsurlardan biri de fıkradır. Türk milletinin mizah anlayışının en belirgin kültür hazinesi olan fikralar, literatürdeki yerini alma sürecinde geçmişten günümüze kadar pek çok araştırmacı tarafından tanımlanmış, tasnif edilmiş; derleme çalışmaları sonunda örneklerle ortaya konmuştur.

Sadece Bingöl'de değil, Türk kültürünün yaşadığı her yerde önemli bir yeri olan avcılık ise birçok anlatı türünde önemli yer edinmiştir. Avcı fıkraları, bu bağlamda değerlendirilen diğer anlatı türlerine nazaran daha mizahi bir yönde olduğu için dikkat çekicidir.

Bu çalışmada Bingöl yöresinde önemli bir sosyal aktivite olan avcılığa bağlı olarak anlatılan avcı fıkraları derlenerek bu konuda bir perde aralanmaya gayret edilmiştir.
\end{abstract}

Anahtar Kelimeler: Gelenek, Halk Edebiyatı, Fıkra, Avcılık, Bingöl

\section{HUNTING TRADITION AND HUNTER ANECDOTES IN BINGÖL}

\begin{abstract}
Folk-literature has been the cultural treasure of our nation for centuries. In this immense treasure, it is possible to come across many verbal cultural elements from epic to legend, from fairy tale to folk tale. One of these elements is anecdotes.

Anecdotes, which are the most prominent cultural treasures of the Anatolian people's sense of humor, have been defined and classified by many researchers from the past to the present in the process of taking their place in the literature and have been presented with examples at the end of the compilation studies.

Hunting, which has a significant place not only in Bingöl but also in all places that Turkish culture lives, has been important for many narrative genres. The hunter anecdotes, compared to other narrative types evaluated in this context in terms of having stronger sense of humour, are more prominent.

In this study, through the compilation of hunter anecdotes emerged by hunting experiences, which is an important social activity in Bingöl region, it was aimed to shed a light upon this issue.
\end{abstract}

Key Words: Tradition, Folk-literature, Anecdote, Hunting, Bingöl.

* Dr. Öğr. Üyesi, Bingöl Üniversitesi, Sosyal Bilimler Meslek Yüksek Okulu, ofelaltuntas@ bingol.edu.tr. ORCID: 0000-0002-8870-4437

(Makale Gönderim Tarihi: 23.03.2021-Makale Kabul Tarihi: 09.04.2021)

DOI: https://doi.org/10.53440/bad.901854 


\section{Giriş}

Avcılık, av hayvanları olarak bilinen yabani hayvanların aranması, izlenmesi ve vurulması esasına dayanan insanlık tarihi kadar eski bir beslenme, geçim, eğlence ve spor türüdür.

Kadim bir tarihe sahip olan bu uğraş içerisinde avlanan hayvanlar, karada avlananlar, havada uçar haldeyken avlananlar ve suda yaşayan hayvanların avlanması olmak üzere üç ana gruba ayrılmıştır. En eski zamanlardan günümüze kadar bu hayvanların avlanmasında değişik yöntemler kullanılmakla birlikte ilk insanlar önceleri korunmak için daha sonra ise beslenmek amacıyla zor şartlarda ve ilkel yöntemlerle avcılıkla uğraşmışlardır. Değişen doğa şartlarına ayak uydurarak gelişen insan ile birlikte avcılık ve avlanma usulleri de değişmiştir. Öyle ki avlanma esnasında tuzaklar, ateşli silahlar hatta ehlileştirilmiş hayvanlar bile kullanılmaya başlanmıştır. Böylece başlangıçta korunma ve beslenme amaçlı yapılan avcılık, yavaş yavaş bir geçim kaynağı ile soyluların, hükümdarların ve kralların boş zamanlarını değerlendirdikleri bir eğlence haline gelmiştir.

Günümüzde avcılık eğlenceli bir uğraş ve sportif faaliyet olarak görülmektedir. Özellikle günümüz insanları şehir hayatından uzaklaşıp doğa ile baş başa olmak, ruhsal ve bedensel yorgunluktan kurtulmak için avcılıkla uğraşmaktadırlar. Modern çağın insanları için zorlu yaşam şartları, stresli iş hayatı ve buna bağlı olarak ortaya çıkan ruhsal yorgunluğun giderilmesinde avcılık, etkili bir faaliyet olarak görülmektedir. Avcılık ile uğraşmayanlar için bedensel yorgunluk ve zaman kaybı olarak görülen bu uğraş aslında bedensel açıdan büyük faydaları olan ve insanın boş vakitlerini iyi şekilde değerlendirdiği bir etkinliktir. İnsanın av esnasında bol oksijen alarak, biriken enerjisini toprağa aktarması ve uzun soluklu yürüyüşler yapması, vücudun kendini tazelemesi açısından oldukça önemlidir.

Avcılığın bir etkinlik ve sportif faaliyet olarak sürdürülmesi ve gelecek nesillere aktarılması bu spor dalıyla uğraşan insanların yani avcıların sorumluluğu altındadır. Her şeyden önce avcının gerek doğaya gerekse de avlayacağı hayvana karşı bazı sorumlulukları vardır. Avcı, yaban hayatına çeşitli dönemlerde katkıda bulunarak kendisinin de dâhil olduğu o muhteşem sisteme faydalı olmaya çalışmalıdır. Tabiatın dengesini sarsacak şekilde hayvan nesillerine zarar vermek hiçbir avcının haz duyacağı bir durum değildir. Daha fazla avlanmak; bir yerine beş tane vurmak, bilinçli bir avcının davranışı olmamakla birlikte kendi egosunu tatmin etmek isteyen avcıların övgü duyduğu bir durumdur. Avcı kendisine göre bir alt tür olan hayvanlara kaçma şansı 
vermelidir. Bu bilinçte olan bir avcı av hayvanlarını tükenmez bir kaynak olarak görmediği için av hayvanlarına karşı saygılıdır. Bilinçli avcı, av hayvanlarını bu konuda çıkartılan kanunların ve yasaların değil de yine kendisinin koruyacağını bilir (Özbay, 2006: 2).

Hiçbir yaptırımın olmadığı yüzlerce yıl evvel, avcıların davranış biçimlerinin bugünkünden daha sağlıklı olduğu, Dede Korkut Hikâyelerinden Begil Oğlu Emre Destanı'ndan alınmış aşağıdaki metinde açıkça görülmektedir:

"Üç yüz altmış atlı Alp ata binerse,

Kanlı geyik üzerine yürüyüş olsa,

Begil, ne yay kurardı ne ok atard,

Hemen yayı bileğinden çıkarırdı,

Boğanın, yabani geyiğin boynuna atardı, çekip dururdu.

Zayıf ise kulağını delerdi, avda belli olsun diye,

Ama semiz olsa boğazlardı.

Ĕger beyler geyik avlarsa,

Kulă̆ı delik olsa,

Begil sevincidir diye Begil'e gönderirlerdi." (Ergin, 1998: 166)

Dede Korkut Hikâyeleri'nden alınan yukarıdaki metinde, avcılık konusunda örnek teşkil edilebilecek davranışlar sergilendiği görülmektedir. Begil zayıf gördügü geyiği avlamamakla birlikte, başka avlanma zamanlarında da avlanmasın diye işaretlemektedir. Begil bu davranışı ile geyiğe yaşama şansı tanımaktadır. Bugün, bu değerler bir ölçüde göz ardı edilmektedir; fakat yine de bu erdemli davranışların varlığının kanıtlanması, bizim için hem teselli hem de gelecek için umuttur.

\section{Avcılığın Kültürümüzdeki Yeri}

Topluluk halinde yaşayan ilk insanları basit av aletleri yapmaya yönelten zaruriyet, vahşi doğa ile verilen mücadeledir. Önceleri canlarını korumak adına vahşi hayvanları öldüren ilk insanlar, daha sonra öldürdükleri bu hayvanların etinden, derisinden ve kemiklerinden faydalanmaya başlamışlardır ki bu durumu insanlık tarihinde bilinçli avcılığın başlangıcı olarak kabul etmek mümkündür. Kuşlar ile küçük av hayvanlarını avlamak için yapılan ilk ilkel avcılık malzemeleri ile birlikte insanların beslenme alışkanlıkları da değişmeye başlamıştır. Bununla birlikte ilk insanlar besin değeri yüksek ve derilerinden olabildiğince fazla yararlanabilecekleri büyük av hayvanlarını avlamaya başlamışlardır. Günümüze kadar ulaşan mağara resimlerinde insanların bu büyük av hayvanları ile yaptıkları mücadeleler tasvir edilmiştir. 
İlkel çağın arkaik insanları, özellikle güçlü av hayvanlarını avlayabilmek için bir araya gelmişlerdir. Toplu halde yapılan bu avlar sayesinde diğer bazı işleri de kolektif olarak yapmaya başlamışlardır. Belirgin toplulukların oluştuğu bu dönemde insanların ilk yerleşim yerleri doğa şartları nedeniyle mağaralar ya da kaya sığınakları olmuştur. Üretimden uzak, avcılık ve toplayıcılığın esas olduğu bu çağda, güçlü bir bölgecilik gelişimi, iş bölümü ve yeni bir üretim biçimi de doğmuştur.

Tarım ve hayvancılığın gelişmesi avcılığı insanın tek geçim kaynağı olmaktan çıkarmıştır; ama yine de özellikle ürünlerin ve evcil hayvanların korunması ile yiyecek sağlamak için avcılık sürdürülmüştür. Ayrıca avcılığın kabile geleneklerinin sürdürülmesinde önemli bir yeri olmuştur.

"Proto-Türk Kültürü; avcı ve atı ehlileştiren bir kültürdür. Türkler, henüz bir devlet kurmadan önce de, belli bir düzen içinde yaşamışlardır. Kabile ve boyların hayatı, belli bir teşkilata dayanmıştır. Türkler; at besleyen, av peşinde koşan insanlardır. Av hayvanlarını izleyerek, uzun mesafeler kat etmişlerdir. Bütün bir boyun katıldığı, büyük sürek avları tertiplemişlerdir. Deri veya kıl çadırlarda oturan, kımız içen ve hayvan besleyen Eski Türkler; avcılığı, günlük hayatlarının bir parçası olarak görmüşlerdir. Beslenme ve ekonomileri yarı yarıya avcılığa dayanır" (Özbay, 1999: 33).

Avcılığa dair birçok inanış mevcuttur. Özellikle İslamiyet’ten sonra avın verimli ve başarılı olması için sahada bulunan evliya yatırlarından yahut avluk yani avın yapıldığı bölgedeki ağaçtan vs. şeytana karşı uğur dilenmektedir. Avcı, av esnasında silahı kendisine yâr olmazsa şeytanı ortadan kaldırmak için yanındaki köpeğini silahının üstünden atlatmakta, köpeksiz bulunduğunda ise bizzat kendisi atlamaktadır. Bu merasim bir nevi ateş kültünden kalma eski bir inançla, kötü ruhlardan temizlenme amacını göstermektedir. Yine eski zamanlardan itibaren av hayvanlarına saygı duyma, avın ve avcılığın ciddiyetini kavrama, ava çıkarken temiz ve arınmış olma gerekliliği oldukça önemli inanışlardandır. Hatta konuyla alakalı çeşitli anlatılarda geçtiği kadarıyla, bazı avcıların ava çıkmadan önceki gece eşleriyle bile beraber uyumadıkları, başka bir odada inzivaya çekildikleri söylenmektedir. Bu gibi inançlara aykırı hareket edilirse, avın verimsiz olacağı düşünülmekte, bu bağlamda av kültüne ait ritüellerin bütünüyle uygulanması gerektiğine inanılmaktadır.

Anadolu'da avcılık, savaşlar için bir ön tatbikat ya da savaşa hazırlayıcı bir eğitim aracı olarak da düşünülmüştür. Bu vesileyle savaş öncelerinde harp 
taklidi olarak büyük avlar düzenlenmiştir. Avcılığın yanında atıcılık ve binicilik de birlikte geliştiği için savaşta gerekli olan cesaret, beden gücü ve irade kuvveti gibi nitelikler bu sayede sürekli olarak güçlendirilmiştir.

Eski çağlarda Anadolu'da avcılar, avladıkları hayvanların et, deri, kemik ve boynuzlarından yararlanmışlardır. Büyük ve küçük hayvanların deri ve kürklerinin kıymetli olanlarını satmışlar, diğerlerinden elbise, kalpak ve çizme, boynuzlarından da yay ve ok yapmışlardır. İslamiyet öncesi kültürümüzde önemli bir yeri olan avcılık, dini bir boyut da kazanmıştır. İslamiyet'in kabulüyle de avcılıkla ilgili dini boyut daha da zenginleşmiştir. Nitekim dini merasim yaptıracak kadar bir kült değeri bulan avcılık muayyen bir kurumlaşma haline gelmiş, yörenin askeri gücünün sembolü karakterini taşımıştır. Buna paralel olarak, manevi toplum hayatının çeşitli cephelerinde kökleşip kalmıştır.

Yüzyıllardır Anadolu topraklarına yayılan çeşitli uygarlıkların insanları, doğadan ve yaban hayvanlarından sürekli yararlanmışlar, yangınlar, savaşlar ve yeni yerleşmelerin de etkisiyle, pek çok yaban hayvanı türünün azalması veya yok olmasına yol açmışlardır; fakat av ve yaban hayvanlarının azalması sadece aşırı avlanmaya bağlanmamalı; olumsuz çevresel faktörlerinin payı da unutulmamalıdır.

\section{Avcılığın Halk Edebiyatındaki Yeri}

Bozkır kültürünün eski ve köklü geleneklerinden biri olarak doğada var olanı toplama ve evcilleştirme etkinliğinin hayvansal yönünü oluşturan avcılık, animizm ve orman kültü anlayışının da önemli bir parçasıdır. Bu bağlamda avcıların av esnasında başlarından geçen olayları abartılı bir şekilde anlattıkları av efsaneleri dikkate değer sözlü edebiyat ürünlerindendir (Türkan, 2008: 70). Ayrıca destanlar, halk hikâyeleri, masallar ve fıkralar da av konusunun işlendiği önemli sözlü edebiyat ürünlerindendir.

Av konusunun ön planda olduğu eserlerin başında Dede Korkut Kitabı gelmektedir. Dede Korkut'ta geçen bölümlerin hemen hepsinde av konusu ön plandadır. Oğuz Beyleri ava çıkmadıkları günü boş geçmiş saymışlardır. Salur Kazan'ın Evinin Yağmalandığı boyda, Salur Kazan, keskin şarabın etkisiyle avlanma isteğini dile getirmektedir. Deli Dumrul, Azrail'i tanımamış ve güvercin haline dönüşüp uçan Azrail'i doğanıyla avlamaya kalkmıştır. Beğil Oğlu Emren boyunda kutsallığa saygı göstermeme ve avda yapılanlarla övünme sonucu bir cezalandırma söz konusudur. Karısının sözüyle ava çıkan Beğil, avın kutsallığına aykırı davranmış, bu yüzden de cezalan- 
dırılmıştır. Salur Kazan'ın Tutsak Olup Oğlu Uruz’un Kurtardığı boyda avlanırken asla yapılmaması gereken bir hatanın üzerinde durulmaktadır. Yine Boğaç'ın azgın boğayı öldürmesi sonucunda kendisine ad verilmesi de Oğuzların töresinde önemli yeri olan ad koyma geleneğinde avın etkisini göstermektedir. Ayrıca Dede Korkut'ta herhangi bir olayı kutlamak için de av düzenlenmektedir. Mesela Bamsı Beyrek bezirgânların canını ve malını kurtarınca Dede Korkut ona ad vermiş ve sonra da ava çıkılmıştır. Dede Korkut Kitabı'nda genellikle sürek avı düzenlenmesinden bahsedilmektedir. Sürek avları sosyal dayanışmayı sağlamaktadır. Kitapta, avın savaş kadar önem taşıdığı vurgulanmakta, askeri manevra kabiliyetini nasıl geliştirdiği de anlatılmaktadır.

Avın önemli olduğu bir başka eserimiz de Manas Destanı'dır. Manas Destanı'nda kahramanlar daha çocukken çalı çırpıdan silah yapıp oyalanmaktadırlar. Manas'ta mızrak, kılıç, balta, ok, süngü, hançer gibi silahlar savaşta kullanılmaktadır. Bu silahların kullanımı güç, cesaret ve kıvrak zekâ gerektirmektedir. Destanda kahramanların kuvvetini, fiziğini ve cesaretini ifade etmek için ayı, kaplan, pars gibi yırtıcı avcı hayvanların isimleri kullanılmaktadır. Manas Destanı'nda kahramanların av kuşları ve av köpekleri, onların en yakın arkadaşlarıdır. Destanda kahramanlar vakit geçirmek için ava çıkmakta ve oyun oynamaktadırlar. Avlanma, yırtıcı kuşlar ve tazılarla yapılmaktadır.

Av kültü ve ona bağlı olarak orman kültü ve dağ kültü, sadece Dede Korkut Kitabı'nda ya da Manas Destanı'nda değil; sözlü anlatı türlerinin çoğunda hem tabiatı ve insan hayatını hem de toplumu düzenleyen kutsallıklar olarak işlev görmektedirler. Bu anlatı türlerinden bir diğeri ise türkülerdir. Çeşitli söz yapılarında av konulu türküler bulunmaktadır. Türkülerin çoğu keklik avı ile ilgilidir. Kekliğin dışında turna, geyik, ceylan, bülbül, ördek gibi av hayvanlarının da konu olarak işlendiği görülmektedir. Konusu doğrudan avcılık olmayan ama av hayvanı olmalarından dolayı avcılığı çağrıştıran, çok bilinen ve sevilen türkülerimiz de bulunmaktadır. Hatta Silifke yöresinde keklik, Bolu yöresinde aman ördek, Bingöl yöresinde kartal oyunları gibi, halk oyunlarımızda da avcılık konusunun işlendiği ve türkülerimizden yararlandığı görülmektedir.

Kerem ile Aslı Hikâyesi'nde Kerem, dağda avcıların bir ceylana tuzak kurduklarını fark eder. Tuzak kurulan ceylan yavruları olan bir ceylandır. Âşık Kerem sazı eline almış ve türküsüyle avcıların kurduğu tuzağı ceylana haber vermiştir: 


\section{Bingöl ARAŞTIRMALARI DERGisi}

"Kova kova indirirler yazıya

Tut ettiler al kınalı tazıya

İş başa düşünce bakma kuzuya

Kaç kuzulu ceylan yad avcı geldi." (Yücel, 2015: 117)

Bazen avcıya hitap, türküyü yakanın kimsesizliğini ya da mahzunluğunu ifade etmektedir:

"Aman avcl vurma meni

Men bu dağın ay balam maralıyam

Maraliyam maraliyam

Avcı elinden ay gülüm yaralıyam" (Yücel, 2015: 344)

Bazı türkülerde ise avcı, genç kızları tuzağa düşüren sembolik avcıya dönüşmüştür:

"Çaya indim oturmam

Elim suya batırmam

Ben bir güzel kekliğim

Her avclya tutulmam" (Yücel, 2015: 432)

Halk türkülerinde en fazla kullanılan sembollerden biri olan keklik, bazı yerlerde av hayvanı, bazı yerlerde bir tabiat varlığı olarak görünse de çoğu yerde sevgilinin ya da genç bir kızın sembolü olarak karşımıza çıkmaktadır:

“Gel gel yanıma keklik

Kastın canıma keklik

Al kınalı parmakların

Batır kanıma keklik” (Yücel, 2015: 571)

Halk türkülerimizin birçoğunda av-avcı konusu ön plandadır. Örnekleri çoğaltmak mümkündür. Bunun dışında avcıların av sevgilerini belirttikleri şiirleri de vardır:

“Keklik öter kayalarda

Tavşan koşar ovalarda

Karda kışta soğuklarda

$B u$ sevdadan vazgeçmem

Vurdum avı alamadım

Avlaklara doyamadim

Caresini bulamadım

Bu sevdadan vazgeçmem 
Doğa benim arkadaşım

Hem yoldaşım hem sirdaşım

Hem ekmeğim hem de aşım

Bu sevdadan vazgeçmem" (K-15)

Avı konu edinen sözlü gelenek ürünleri içerisinde maniler de vardır:

“Gönüldür aldırınca

Ummana daldırınca

Ceylan gözüne kurban

Avcılar saldırınca" (Elçin, 1990: 94)

Bu manide avcı-ceylan ilişkisinden bahsedilmektedir. Türkülerimizde de sık rastladığımız bu konu, avcının zalimliğinden bahsetmektedir. Burada avcının rakip, ceylanın ise sevgili olduğunu düşünmek mümkündür.

"Av ben değilsem bile

Ava olmasin hile

Yer değiștirsin avcl

Sıkıysa sıkabile” (Elçin, 1990: 137)

$\mathrm{Bu}$ manide ise gerçek av-avcı ilişkisinden bahsedilmektedir. Avda avcılar tarafından av hayvanlarına karşı hile ve aldatma çok olduğu için avcının mertlikle av yapması gerektiğinden bahsedilmektedir.

Masallarımızda da av konusunun sıklıkla yer aldığı görülmektedir. Av konulu masalların olağanüstülükleri yönüyle av konulu fikralara benzediğini düşünmek de mümkündür. Av motifi masallarda şu işlevlerle yer almaktadır:

-Av, masallarda babadan oğula geçen ve genelde tercih edilmeyen bir meslek olarak iş görebilmektedir.

-Av, padişah ve şehzadelerin ya da diğer masal kahramanlarının, sıkıntılarını gidermek, daraldıklarında kendilerini eğlendirmek amacıyla müracaat ettikleri bir uğraş olabilmektedir.

-Masallarda av, günlük yiyecek temini için kahramanların sık sık başvurdukları bir iş olarak öne çıkmaktadır.

- Nadir de olsa av motifi, 'Dede Korkut Kitabı'nda, Dirse Han Oğlu Boğaç’ın hikâyesinde de görüldüğü gibi bir insana tuzak kurup öldürmek için kullanılmaktadır.

-Av, sağaltım amacı ile de yapılmaktadır. Ak Atlı Oğlan masalında boğazı şişen padişaha, hekimler ancak av etinin suyunu içerek iyileșebileceğini söylerler. (Türkan, 2008: 73) 
• Masallar, olağanüstülükleri yönüyle ön planda olduğu için av konusu bazen hayvanların birbirlerini avlamaları ya da birbirlerini avcıların elinden kurtarmaları şeklinde karşımıza çıkabilmektedir. Bingöl yöresinde anlatılan Kurt ile Kaplumbağa masalında kaplumbağanın, kendisiyle alay eden kurdu avcıların elinden kurtarması anlatılmaktadır. Bu masalda avcı, zalim bir tiptir.

-Masalların en önemli motiflerinden olan devler, insanların başına sürekli bela olmuşlardır. Bu devlerin yok edilmesi ise güçlü avcılara düşmektedir. Yine Bingöl yöresinde anlatılan Dev ile Üç Kardeş masalında, kardeşlere türlü türlü hileler yapan dev, bir avcı tarafından öldürülmüştür.

Av konulu efsanelere bakınca çalışmamıza konu olan Bingöl ilinin adının çıkış efsanesi de önemli bir örnektir. Evliya Çelebi, Seyahatnamesi'nde bu efsaneyi şu şekilde anlatmıştır. "Bir avcl, bir keklik vurmuş. Onu gölde temizlerken, kuş canlanmış ve göle dalıp kaybolmuş. Gölün ab-ı hayat kaynağı olduğu ortaya çıkmıştır. Bu sır ortaya çıkınca göl Allah'ın emriyle bin parçaya bölünmüş ve hangisinin ab-ı hayat kaynağı olduğu bilinmez olmuş. Bu bin parçaya bölünen gölü görenler de 'Hani nerde o bahsettiğin göl? Bu bir göl değil ki hezar göldür.' demişlerdir. Böylece o göllerin bulunduğu çevreye hezar (bin) göl denmiştir" (Alay, 2008: 15). Yine halk arasındaki inanışa göre yılda bir kez Hızır Peygamber'in ab-ı hayat gölünde yıkandığına ve abdest tazelediğine inanılmakta; ama hangi göle geldiği ve ne zaman geldiği bilinmemektedir.

Yukarıda sayılan örneklerin dışında destanlarda, efsanelerde, masallarda, halk hikâyelerinde, şiirlerde, manilerde ve diğer birçok sözlü anlatı türünde av-avcı ilişkisine rastlamak mümkündür.

\section{Bingöl'de Avcılık Geleneği}

Avcılık konusunun Bingöl'de uzun bir maziye sahip olduğu bilinmektedir. Bingöl; tabiatı, iklimi, bitki örtüsü ve bilhassa ormanlık alanlarıyla büyük bir av potansiyeline sahiptir. Birçok av hayvanının barındığı yörede son yıllarda avcılık çok daha önemli ölçüde artış göstermektedir. Özellikle yöre insanının ava olan ilgisi dikkate değerdir. Arazi dağlık ve gür ormanlarla kaplı olduğu için av hayvanların barınması ve yaşaması mümkün olmaktadır.

Av organizasyonları, 1950 yılında kurulan Bingöl Avcılar ve Atıcılar Derneği tarafından organize edilmektedir. Avcılar ve Atıcılar Derneği kurulduğu günden beri yöredeki avcılar için çok önemli bir yere sahiptir. Avcılar sadece av dönüşlerinde değil, gün içerisinde de sürekli olarak kulübü ziyaret etmekte, günlerinin çoğunu burada geçirmektedirler. Ayrıca şehrin merkezi bir ye- 
rinde bulunan Avcılar Kulübü'nün mülkiyetinin avcılar tarafından alınarak derneğe bağışlanmış olması da avcılık konusunun Bingöl'de ne kadar önemli bir yeri olduğunun göstergesidir.

Keklik ve bıldırcın Bingöl dolaylarında en çok avlanan av hayvanlarıdır. Bıldırcının avlanma mevsimi kısa olduğu için, keklik avı halk arasında daha fazla tercih edilmektedir. Öyle ki bazı avcıların avda vurdukları yaralı kekliği şehre getirip tedavi ettirdikten sonra evlerinde besledikleri de sıklıkla görülmektedir. Buradan da anlaşılacağı üzere avcılık sadece av hayvanlarının etinden faydalanmak için uğraşılan bir spor faaliyeti değildir. Keklik ve bıldırcının dışında en fazla rağbet gören av hayvanları ördek ve tavşandır. İlde ağustos-eylül aylarında bıldırcın; eylül-ekim-kasım aylarında keklik, tavşan, çulluk, tilki; ocak-şubat aylarında da tavşan, keklik, kurt, sansar gibi hayvanlar avlanmaktadır. Ayrıca bazen köylere ve köylülere zarar vermesini engellemek için domuz avı da yapılmaktadır.

Av faaliyetleri bazen şehre yakın yerlerde, bazen de şehrin yüzlerce kilometre uzağında gerçekleştirilmektedir. Örneğin bıldırcın avı şehre yakın olan Bingöl Ovası'nda; keklik avı, mevsimine göre Genç, Sancak, Kiğı kırsallarında yapılmaktadır. Ördek avı, dere ve göllerin olduğu yerlerde; tavşan avı ise Sancak, Kiğı, Yayladere, Yedisu, Karer kırsallarında yapılmaktadır. Bunun dışında Murat, Göynük, Yayladere, Kiğı, Gülbahar, Gayt ve Çabakçur nehirlerinde de balık avı yapılmaktadır.

Av sezonlarında Bingöl'de sadece yerli avcılar değil, çevre illerden gelen avcılar da farklı bir renklilik oluşturmaktadır. Avcılar avlanabilmek için öncelikle Avcılar ve Atıcılar Derneği'nin açtığı kurslara devam etmekte, Çevre ve Orman Müdürlükleri'nden gerekli sertifikayı edinmekte, bunun sonucunda avlanmaya hak kazanmaktadırlar. Yörenin avcıları genellikle iyi silah kullanmakta, iyi avlanmaktadırlar. Öbür yandan av hayvanlarına saygılıdırlar. Av sezonlarının dışında avlanmamaktadırlar.

Bingöl'de yaşayan avcılar genellikle çok genç yaşta av sporuna gönül vermiş, ava büyükleriyle başlamış, bu sayede merak salarak av yerlerini ve av hayvanlarını tanımış, avlanma yöntemlerini öğrenmişlerdir. Bingöl'de avın bir tecrübe işi olduğuna inanılmaktadır. Bu yüzden ava ilk gelenlere bir süre tüfek verilmemektedir. Gelen kişinin tüfeği varsa da o tüfek ortamdaki en tecrübeli avcıya teslim edilmelidir. Av esnasında kullanılmasına müsaade edilmez. Av bittikten sonra avcı adayı tüfeğini alıp atış talimi yapabilmektedir. 
Bingöl'de av, belli bir kesimin uğraştığı özel bir spor değildir. Hemen herkesin belli dönemlerde av faaliyetleri olmuştur. Bingöl'ün küçük bir il olması münasebetiyle av sporuna gönül vermiş insanlar genellikle birbirlerini tanımaktadırlar. Bu durumda Avcılar ve Atıcılar Derneği'nin aktif olmasının da payı vardir.

Avcılar sadece birbirlerini tanımakla kalmaz, halk arasında da tanınırlar. $\mathrm{Bu}$ anlamda Bingöl'de uzun yıllar av faaliyetlerinde bulunan ve çevrelerine av sevgisini benimseten birkaç isimden bahsetmek gerekir: Palulu Mahe Dayı, Gazeteci Abdurrezzak, Zabıta Emin, Paşa Aybek, Arif Çelikkaya, Lütfü Aydoğdu, Sadin Aydemir, Mehmet Bozkuş, Sıtkı Börü, Sıddık Bazencir, Rıfat Elaltuntaş, Ahmet Dursun, Cemal Çelikkaya bu avcılardan birkaçıdır. Saydığımız avcıların bazıları şu an hayatta değildir; fakat hepsi Bingöl'de gerek halk arasında gerekse de diğer avcılar tarafından saygıyla anılan değerli insanlardır.

\section{Fıkralarda Avcılığın Yeri}

Anlatmaya dayalı sözlü kültür ürünlerinden biri olan fıkra, "Kısa ve özlü anlatımı olan, nükteli, güldürücü küçük hikâye” (Öts 1995: 916) şeklinde tanımlanmaktadır. Dilbilimsel olarak kökeni Arapçaya dayanan fıkranın kültürümüzdeki adlandırılma serüveni ise Divanü Lügati't-Türk'te yer alan ve külüt sözcüğüyle başlayıp bir edebî tür olarak literatürde asıl kimliğini buluncaya kadar latife, hikâye, kıssa, destan, masal gibi adlarla diğer anlatı türleri içinde değerlendirilmiş; şaka, nükte, mizah, latife ve fikra terimleriyle de son dönemde anlatı geleneğinde ve yazın hayatında yerini alarak sonlanmıştır (Elçin, 1993: 566).

Vehbi Cem Aşkun, "Fıkralar, geçmiş olayların küçültülmüş diyemleridir" (Aşkun 1940:145) şeklinde tanımladığı fıkraların hayatın gerçeklerini içinde gizlediğini ve devirlerin kendine özgü özelliklerini ve inceliklerini yansıttığını ifade etmektedir. Eker vd. ise fikrayı efsane, masal, menkıbe gibi türlerin hepsini özünde taşıyan bir bileşke olarak tanımlamakta ve bu bileşkeyi temsilen eriyik kabı terimini kullanmaktadır (Eker vd., 2003: 319).

Terim ya da kavram olarak fıkrayı tanımlamaktan öte, sözlü gelenekte anonim bir anlatı türü olarak milli kültür değerleri arasında yer alan fıkrayı tanımanın daha verimli olacağı kanaatiyle kapsamlı bir yaklaşımla fıkrayı şöyle tanımlamak mümkündür: "Fıkra, hikâye çekirdeğini hayattan alınmış bir vak'a veya tam bir fikrin teşkil ettiği kısa ve yoğun anlatıml, beșerî kusurlarla içtimaî ve günlük hayatta ortaya çıkan kötü ve gülünç hadiseleri, çarpık- 
lıkları, zıddiyetleri, eski ve yeni arasındaki çatışmaları sağduyuya dayalı ince bir mizah, hikmetli bir söz, keskin bir istihza yoluyla yansıtan; umumiyetle bir fıkra tipine bağlı olarak nesir diliyle yaratılmış, sözlü edebiyatın müstakil şekillerinden ibaret yaygın epik-dram türündeki realist hikâyelerden her birine verilen isimdir" (Yıldırım, 1999: 3).

Anlatmaya dayalı edebî metinlerin türlerini tanımlamak ve biçimlendirebilmek için diğer pek çok edebî metinde olduğu gibi belli kriterler ve ayırt edici unsurlar mevcuttur. Masallardaki formeller, hikâyelerdeki motifler, fikralardaki nükteler bunlardan bazılarıdır. Böyle olunca anlatı türleri için de bir kültür göçünden veya uluslararası etkileşimden bahsetmek mümkündür; fakat fıkra, Anadolu insanının sıcak espri anlayışı ile farklı bir dinamizm kazanmaktadır. Kültürel etkileşim çerçevesinde aynı konuyu belki neredeyse aynı fıkra tipini işleyen bir İngiliz veya Amerikan fıkrası ile Türkçe anlatılan bir fıkra arasında esprinin canlılığı ve sıcaklığı açısından derin farklılıklar görülmektedir. Nükteye oturtulan ironi; soğuk Amerikan esprilerinde dudaklarda küçük bir tebessüm yaratırken, bir Nasrettin Hoca, Bektaşi fıkrası ya da bir avcı fıkrasında gülmekten insanın karnını ağrıtacak, gözlerinden yaş getirtecek bir doğal reflekse dönüşebilmektedir. Bu da tarihsel sürecin bu güne kadar taşıdığı fıkranın bizde yaşamla ne kadar iç içe ve işlevsel bir anlatı olduğunu göstermektedir. Bu türle ilgili olarak önemsenmesi ve ifade edilmesi gereken asıl nokta, anlatıların yaşantıya dayalı olması ve nükteyi ön planda tutma özelliğidir. Tüm bu söylediklerimizden hareketle fıkrayı şöyle tanımlamak mümkündür:

Fıkra; halkın düşüncesini, sosyal iletişim tercihlerini, yaşam biçimini, töresini, toplumsal kurumlarını kısacası halk kültürünün herhangi bir elementini, zeki bir yaklaşımla bir ileti haline getirip en sivri uçlarını törpüleyerek, sezdirme yoluyla ifade eden ve merkezine nükteyi alan, özlü durum öyküleridir. Fıkranın anlatmaya dayalı diğer edebi türlerden farkı ise, hayatla doğrudan iç içe olmasıdır.

Tanımlarda da belirtildiği gibi fikralar, sözlü kültür ortamında gelişen ve durum belirten kısa öykülerdir. Fıkralarda ayrıntılar pek yer almamaktadır. Hayattan bir anının en çarpıcı noktasını yakalayarak fotoğraflayan fıkralar, gerçek ya da gerçekleşmesi mümkün olaylardan kaynaklanmaktadır.

Bazen yarı fantastik olarak kurgulanan fıkralarda yer alan fantastik unsurların da bir alegori taşıdığı görülmektedir. Avcı fıkraları bunun en belirgin örnekleridir. Fıkralar; toplumun, idarecilerin ya da kişilerin aksak yönlerini eleştirerek ironik bir ifadeyle, mevcut durumdan bir ders çıkarmayı amaçla- 
maktadır. Bu maksatla ahlak, gelenek, din, eğitim, siyaset, talih, adalet, sosyal kurumlar gibi pek çok konu fikralarda işlenebilmektedir. Bütün bu konu çeşitliliğine ve kapsam genişliğine rağmen fıkralarda olay örgüsü mümkün olanın en kısasıdır. Verilmek istenen mesaj nükteye saklanmakta ve hazırlık kısmında pişirilen konu tek bir cümleyle ortaya konmaktadır. Fıkralarda eleştirilen durum o kadar tanıdıktır ki fıkrayı dinleyen herkes anlatılan fıkradan kendi payına düşen hisseyi çıkarmakta ve almaktadır. Bu yönüyle bakıldığında fıkranın toplumsal bir özeleștiri mekanizması olduğunu söylemek mümkündür. Eğer fıkra kendisine yüklenen bu işlevi yerine getirebilmiş ve eleştiriye dayanan mekanizma işlerlik kazanmışsa tür kendine özgü biçime kavuşmuş demektir. Fıkraların kendine özgü bu biçimi, işlevinin büyüklügüyle orantısız bir hacme sahiptir. Yıldırım'ın “Toplumsal sözel eleştiri dokumaları/metinleri" ( Yıldırım, 1998: 234) adını verdiği fıkralar, yine toplumun yarattığı doğruları, kendi üyelerince bilinir ve kabul edilir kılmakla ilgili olarak bulduğu bir yoldur. Bu yolla mesajlarını iletmekte ve dönütünü sağlamaktadır.

Her fikra aynı gayeyi taşımasa bile, genel olarak fıkraların amacı gülerken düşündürmek ve bir ders vermektir. Fıkralar, konuları itibariyle tanınmış ünlü tiplerin yaşadığı olayları anlatabileceği gibi (Nasreddin Hoca, İncili Çavus, Bekri Mustafa vb.), bir topluluğu temsil eden (Bektaşi, Baskilli, Kayserili, Karadenizli vb. ) veya bir meslek gurubunu temsil eden konularla ilgili olarak da işlenebilmektedir. Çalışma konumuz olan avcı fıkraları da gerek konuları itibariyle gerekse de mizahi yönüyle dikkate değerdir.

\section{Bingöl'de Avcı Fıkraları}

Avcı fıkraları; av hayatını, av-avcı ya da avcı-avcı ilişkisini konu edinen yoğun mizah içerikli fıkralardır. Bu fıkralarda ilk bakışta belirgin olan bazı özellikler vardır. Bunların başında avcı yalanları, avda yaşanan ilginç olayların abartılarak veya övünülerek anlatılması gelmektedir. Ayrıca genç avcıların yaşlı avcılara nispet yapması, yaşlı avcıların altta kalmamak için türlü yalanlara başvurması, acemi avcıların küçümsenerek alay konusu edilmesi gibi durumlar söz konusudur; fakat fikralar dikkatli incelendiğinde konuyla ilgili sadece basit mizahi durumların işlenmediği, aynı zamanda bu fıkraların tarihi ve sembolik birtakım temelleri olduğu da görülmektedir.

Tarihi boyunca silahı hep iyi kullanan, attığını vuran, mazisi ve savaşları hep zaferlerle dolu olan bir milletin fertleri doğal olarak av şölenlerinden de zaferle dönmelidirler. Milletin fertleri hangi sosyokültürel, sosyoekonomik veya siyasi yapıya sahip olursa olsun bu durum karşısında ortak bir tavır ser- 
gilemektedirler. Güç, Anadolu insanının en önemli dayanak noktası olduğu için savaş meydanında düşmanını yenen birinin ava çıktığında da doğaya, av hayvanlarına ve diğer avcılara karşı üstünlük sağlaması gerektiğine inanılmaktadır. Aksi takdirde güçsüzlük ve yeteneksizlik durumu ortaya çıkar ki, bu da hoş karşılanan bir durum değildir. Avcı fıkraları da bu bağlamda düşünülecek olursa, fıkralarda eski inanışların ve geleneklerin sıkça yer alması daha rahat anlaşılacaktır. Hiçbir avcı, avdan eli boş döndüğünü anlatamaz. Anlatırsa insanların onu ayıplayacağını ve ona güleceklerini düşünür. Böyle olunca da bereketsiz geçen av törenleri, av sonrası anlatılardaki yalan ve abartılarla bertaraf edilmektedir. Avcı fikralarının asıl konusunu da bu durum oluşturmaktadır.

Bingöl'de anlatılan ve bu çalışmaya kaynaklık eden avcı fıkraları incelendiğinde, fıkraların diğer yörelerde anlatılan avcı fıkralarıyla paralellik olduğu görülmektedir. Ortak bir şuurla ortaya çıkıp her yerde anlatılan avcı fıkralarının Bingöl örneklemelerinde de abartının, yalanın ve övünmenin ön planda tutulduğu görülmektedir. Avcılar, avda gösteremedikleri performansı av dönüşü anlattıkları olaylarla göstermektedirler. Anlatılan fıkraların birçoğu avda gerçekleşen durumu değil; olması istenilen durumu yansıtmaktadır. Yani avcılar hayal dünyalarında geliştirdikleri olayları avda yaşanmış hissi vererek anlatmaktadırlar. Böylece çevrelerinde itibar görmeyi hedeflemektedirler.

Fıkralar bazen gerçeğe yakın gibi görünse de birçoğu gerçek hayattan uzaktır. Bu fıkralarda özlü sözler pek yer almamakta; ama nükteli veya tepkili sözler sıkça karşımıza çıkmaktadır. Fıkralarda yer belli olmakla birlikte zaman konusunda pek belirginlik yoktur. Sadece yapılan avın cinsine göre yılın hangi ayı olduğu anlaşılabilmekte; fakat bunun dışında genel bir zaman dilimi belirtilmemektedir. Fıkralar kısa ve yoğun olmasına rağmen sonunda ders verme gibi bir amaç taşımamaktadır. Mizahi yönü daha ağırdır; güldürücüdür, eğlendiricidir.

Fıkralar incelendiğinde bazılarının farklı yörelerde farklı isimlerle varyantlaştığını görmek mümkündür. Örneğin Bingöl Dağları'nda avcının biri bir gün diye başlayan bir fıkranın başka bir yerde Bolu Dağı'nda bir avcı bir gün şeklinde başladığı, şahıs ve mekânın dışında aynı konuyla anlatıldığı görülmektedir. Bu durum metinler arasında ilişki olduğunun bir göstergesidir. Aynı zamanda avcıların başka yörelerdeki avcılardan dinledikleri av maceralarını, kendileri yaşamış gibi anlatmaları da varyantların yaygınlaşmasını sağlamaktadır. 
Eski halk inanışlarının da Bingöl'de anlatılan avcı fıkraları üzerinde önemli etkisi vardır. Av kültünün en önemli dayanaklarından olan dağ iyesi, orman iyesi, su iyesi ve bununla birlikte fıkralarda formelistik sayıların sık sık geçmesi avcı fıkralarını sadece gülünç ve abartılı birer fıkra konumundan çıkarıp farklı bir boyuta getirir.

\section{Örnek Fıkraların Tematik Yönden İncelenmesi}

Bu çalışmada Bingöl'den derlenen yüzün üzerinde fikra içerisinden kırk fıkra örneği seçilmiş ve örnek olarak kullanılmıştır. Genel olarak derlenen fıkralar incelendiğinde, fıkra örneklerinin konuları itibariyle birbirine yakın olduğu göze çarpmaktadır. Bünyesinde bütün mizah teorilerini bulunduran avcı fıkraları genellikle avcıların birbirlerine güç gösterilerini ifade ettikleri bir sözlü anlatı türü olarak literatürdeki yerini almıştır. Bu bağlamda anlatıların övünme, yalan, küçümseme, kurnazlık gibi konuların ekseninde olması doğaldır. Üstünlük teorisi, rahatlama teorisi ve uyumsuzluk teorisi avcı fıkralarının mizahi yönünü en iyi şekilde açıklayan teorileridir.

Üzerine en çok yorum yapılan ve en uzun süre kabul gören mizah teorisi üstünlük teorisidir. Bu teori Platon'dan beri tartışılmaktadır. Platon'a göre gülme, zayıf ve zararsız olmak şartıyla, bir kişinin diğerleri üzerinde üstünlük kurma isteğinin ifadesidir. Platon, gülmenin temelinde kendini bilmeme yatar. Kişi kendini olduğundan daha akıllı, daha zengin, daha namuslu sandığı sürece komiktir, demektedir. Aristoteles de aynı görüşe katılmaktadır. Poetics'te gülünçlük alt düzeyden olan insanlarda görülür. Eğer insanlar gerçek hayatlarından daha iyi olarak tanıtılırlarsa onların hataları tragedyanın konusu olur, demektedir. Uyumsuzluk teorisi, gülmenin duygusal yönünden çok, düşünce ve mantık yönüne ağırlık vermektedir. Üstünlük teorisinde ise ilgimiz daha çok duygu yönüne kaymakta, eğlence, zafer kazanma duygusu ve galibiyetten dolayı insanın kendi kendini kutlaması söz konusu olmaktadır. Hâlbuki Uyumsuzluk teorisinde umulmadık, mantıksız ve uyumsuz olan bir şeye karşı zihnin tepkisi, gülmenin sebebi olarak kabul edilmektedir. Gülme teorilerinden biri de rahatlama teorisidir. Sıkıntıdan, stresten kurtulmaya ve rahatlamaya ağırlık veren bu teori, üstünlük ve uyumsuzluk teorileriyle birleșen bir alana sahiptir. Mesela, tehlikenin ortadan kalkması ile duyulan rahatlama veya önceki durumumuzdan daha iyi bir halde bulunmamızın verdiği duygu gülme sebebidir diyen üstünlük teorisiyle rahatlama teorisi aynı alanda birleşmektedir (Türkmen, 1999: 25).

Nasreddin Hoca fıkralarının mizahi yönünü değerlendirirken faydalanılan bu teoriler avcı fıkralarının mizahi yönünün açıklanmasında da önemli 
bir yere sahiptir. Çalışmamızdaki örnek fıkra metinlerine bakıldığında, fıkraların konusu ne olursa olsun bu mizah teorilerinin etkisi altında olduğu anlaşılmaktadır. Avcı fıkraları, avcılar arasındaki rekabetin ve gücü ispat etme arzusunun neticesinde doğmuş anlatılardır. Dolayısıyla birbirlerine gücünü göstermek isteyen insanlar birbirlerine üstünlük sağlamak isteyeceklerdir. Bu yüzden yaptıklarına kat kat eklemelerde bulunacaklar ve durumu bu şekilde izah edeceklerdir. Üstünlük teorisine bağlı olarak ava giden bir kişinin yaptıklarına eklemeler katarak anlatması, anlatıyı komik bir hale getirecektir. Avda yaptıklarına olağanüstü eklemelerde bulunarak anlatan bir insan, karşısındakilere karşı mantıksız gelecektir. Uyumsuzluk teorisine bağlı olarak böyle mantıksız ve umulmadık bir durum karşısında zihnin tepkisi gülme olacaktır. Av her zaman tehlikelerle doludur. Avcının başına her an her şeyin gelmesi mümkündür. Fıkralarda avcının zor bir durumdan kurtularak rahatlığa kavuşması ise mizah teorilerinden rahatlama teorisine uygun olacaktır. Ekte sunulan örnek fıkra metinleri, avla alakalı birçok farklı konu ihtiva etmektedir. Avcı fikraları genellikle av öncesinde, av esnasında ve av sonrasında meydana gelen durumların abartıyla ve yalanla karışık anlatıldığı fikralardır. Yalan ve abartı avcı fıkralarının olmazsa olmazıdır. Zaten bu fıkraların mizahi açıdan güçlü hale gelmesinin sebebi yalana ve abartıya fazlasıyla yer verilmesinden kaynaklanmaktadır. Yalan hiçbir toplum tarafından hoş karşılanmayan, insanların başına türlü türlü belalar açan ve ortaya çıtığında kişi için utanç kaynağı haline gelen bir olgudur. Durum böyleyken avcı fikralarının en aslî öğesi olan yalan, insanların birbirlerine karşı üstünlüğünü ispat etmek için kullanılan bir araç haline gelmektedir. Fıkralarda yalan söylenmesinden daha kötüsü ise yalanın ortaya çıkmasıdır. Yalanın ortaya çıkması bir yenilgidir. Her avcı avla alakalı anlattıklarına yalan eklemektedir; fakat yalanın çok belirgin olması, o avcının yeteneksizliğinin göstergesidir.

Bingöl'de anlatılan avcı fıkralarında, avcıların acemilikleri de konu edilmektedir. Fikralarda avcılar, acemilik karşısında ustalığın ne denli zor ve tecrübe gerektiren bir süreç olduğunu vurgulamaktadır. Bu fikralarda belirgin bir şekilde uyumsuzluk teorisinin özellikleri görülmektedir. Avcıların acemiliklerini anlatan fikralarda, anormal olaylar karşısında gülünç bir durumla karşılaşmak mümkündür.

Fıkralarda üzerinde durulan konulardan biri avcılar arasındaki rekabettir. Avcılar fıkralarda kendi av stillerini, av araç gereçlerini övmekte, rakip avcıları ise eleştirmektedir. Avcıların kendilerini yüceltip rakip avcıları küçümsediği fikralar, üstünlük teorisiyle doğrudan uyumludur. Avcılık, yapılan işin tabiatı gereği doğaya ve diğer avcılara karşı galip gelmeyi gerektirdiği 
için, fikralarda avcıların birbirlerini alt edip üstün gelme gayretinde olmaları anlaşılabilir bir durumdur; fakat bu durum bazı fikralarda avcıların birbirleriyle alay etmeleri, uyumsuzluk teorisine bağlı mantıksız ya da umulmadık hareketlerle karşılaşmaları şeklinde ortaya çıkabilmektedir. Bununla beraber kimi fikralarda avcıların sadece birbirleriyle değil, av hayvanlarıyla da rekabet içerisinde oldukları görülmektedir. Bu konunun işlendiği fıkralarda avcıların kendilerinde eksik kalan duygu, durum ya da becerileri av hayvanlarına üstün gelerek gidermeye çalışmaları söz konusudur.

Fıkralarda işlenen konulardan bir diğeri kurnazlıktır. Avcılar anlattıkları fıkralarda gücün ve becerinin bazen tek başına yeterli olmayacağını, bazen gerek hayatta kalabilmek için doğaya gerekse de avlanabilmek için av hayvanlarına karşı kurnaz davranmak gerekebileceğini vurgulamaktadırlar.

Genel olarak Bingöl'de anlatılan avcı fıkraları, farklı yörelerde anlatılan mizah içerikli örneklerle benzerlik göstermekte; fakat avın ruhu, ciddiyeti, avda paylaşımın önemi, sağlıklı yaşam için av sporunun gerekliliği, avlakların temiz tutulması ve av hayvanlarına saygı gibi sosyal içerikli konuların da yer tuttuğu görülmektedir.

\section{Sonuç}

Toplumların kültür tarihlerinin önemli bir parçasını oluşturan halk bilgisi ürünleri, halk hayatının her alanında onu ifade eden biçimlerde yer almaktadır. Bu yer alış içinde mevcut bulunan estetik kaygı, insanın güzel olana merakı nedeniyle onu kalıcı kılmaktadır. Kalıcılığın ana dayanağı ise gelenekleşmiş halk bilgisi ürününün onu olușturan halkın bütün üyelerince tanınıyor olmasıdır. Bu bakımdan halka ait olan bir folklor malzemesinin halkın sosyal hayatından izler taşımaması mümkün değildir. O halde bütün folklor ürünlerinin yapısında onu oluşturan sosyal çevreden izler vardır.

Geleneği, sözlü kültür aktarımı yoluyla sürekli kılan halk anlatıları da bütün olarak halk felsefesini ifade eden birer form olarak kabul edilmeli ve muhtevasındaki her yapıya bir sosyal olay ya da olgu olarak bakılmalıdır. Bu bir yöntem olarak belirlenmeli ve sahadan derlenen her halk anlatısı, yalnızca bir metin tespiti olarak kalmamalıdır.

Bu çalışmalar yapılmakla hayatın her alanıyla ilgili geleneği sürdürmek noktasında birincil sözlü kültür ortamında bir kültür taşıyıcısı işlevi yüklenen fikralarımızı halk hafızasından derleyip yazılı kültür ortamında veya elektronik kültür ortamında yeni kuşaklara taşımak mümkün olacaktır. Her devirde sosyal hayatın aynası olan bu temsiller, yazıya geçtikten sonra bile 
dilden dile aktarım sürecinde yeni kazanımlarla özünden kopmadan yepyeni sosyal olaylara misal olabilecektir. Bu da sözlü kültür aktarımı sürecinin yazıya aktarımdan sonra da halka mal olma, yeni ağızlardan birikimler edinme biçimiyle sürdüğünü, her yeni anlatının yeni bir metin olduğu gerçeğini ortaya koyduğunu göstermektedir.

Bu noktadan hareketle, Bingöl'de Avcılık Geleneği ve Avcı Fıkraları adlı çalışmamızı avcılık hakkında genel bilgiler, avcılığımızın edebiyatımızdaki yeri ve örnek avcı fıkralarından oluşan giriş ve iki ana bölümle ele aldık.

Yaptığımız araștırma ile avcılığın güce ve beceriye dayalı bir aktivite olması neticesinde toplum nezdinde önemli bir yeri olduğunu gördük. Anadolu insanı en eski çağlardan beri avcılığı kendine düstur edinerek önemli faaliyetlerde bulunmuştur. Buna bağlı olarak avcılık, sözlü kültürümüzün hemen her türünde karşımıza çıkmaktadır. Toplum; av konusunu içeren destanları, efsaneleri, halk hikâyelerini, masalları, türküleri zevkle dinlemiştir; fakat avcı fıkraları için durum pek de böyle değildir. Avcı fıkraları, avı konu edinen diğer türlerin aksine yalan, abartı, övünme, küçümseme gibi konularla karşımıza çıkmaktadır. Böyle olunca da diğer anlatılardaki güçlü, mert, cengâver avcı modeli; avcı fıkralarında kendini öven, yalan söyleyerek karşısındakilere karşı üstün gelmeyi hedefleyen avcı modeline dönüşmüştür.

$\mathrm{Bu}$ çalışmayı yaparken konunun başlı̆̆ı doğrultusunda; yazılmış tezlerden, çeşitli süreli ve süresiz yayınlardan faydalandık. Fıkra derlemelerini ise yakın akrabalardan ve arkadaşlardan yaptık.

Bu çalışma ile derlenen fıkraların, yerelden ulusala ve oradan da küresele yayılma sürecinde yazılı kültür ortamına taşınmasıyla birlikte halk edebiyatının sözlü kültür unsurlarına bir katkı sağlayabilmek, amaca ulaşmanın en önemli adımı olarak kabul edilmiştir. 


\section{Bingöl ARAŞTIRMALARI DERGisi}

\section{Kaynakça}

\section{a. Sözlü Kaynakça ${ }^{1}$}

(K-1) Kadir BATARAY, Bingöl, 1980, üniversite, arkadaşlarından dinlemiş, serbest meslek.

(K-2) Salim BAZENCİR, Bingöl, 1965, lise, abisinden dinlemiş, serbest meslek.

(K-3) Sıdık BAZENCİR, Bingöl, 1958, üniversite, arkadaşlarından dinlemiş, emekli.

(K-4) Eshap BÜRLÜKARA, Bingöl, 1981, lise, arkadaşlarından dinlemiş, serbest meslek.

(K-5) Ahmet CAF, Bingöl, 1982, doktora, arkadaşlarından dinlemiş, öğretim üyesi.

(K-6) Rasim DİNÇALP, Kiğı, 1970, lise, babasından dinlemiş, kamu personeli.

(K-7) Fuat ELALTUNTAŞ, Bingöl, 1979, lise, babasından dinlemiş, serbest meslek.

(K-8) Ramazan ELALTUNTAŞ, Bingöl, 1978, lise, arkadaşlarından dinlemiş, vefat.

(K-9) Rıfat ELALTUNTAŞ, Bingöl, 1945, ortaokul, arkadaşlarından dinlemiş, vefat.

(K-10) Bayram ERKUŞ, Bingöl, 1974, lise, arkadaşlarından dinlemiş, serbest meslek.

(K-11) M. Fatih GERBOĞA, Bingöl, 1988, arkadaşlarından dinlemiş, serbest meslek.

(K-12) Cemal Yümnü KULU, Palu, 1966, üniversite, arkadaşlarından dinlemiş, vefat.

(K-13) Ali Rıza KURTARAN, Karlıvva, 1968, üniversite, arkadaşlarından dinlemiş, kamu personeli.

(K-14) Zeki SİNEN, Genç, 1988, üniversiteye devam ediyor, abisinden dinlemiş, serbest meslek.

(K-15) Enver YILDIZ, Gökdere, 1977, üniversite, arkadaşlarından dinlemiş, kamu personeli.

\section{b. Yazılı Kaynakça}

ALAY, Okan, Bingöl Masalları (İnceleme-Metin), (F. Üni. Sos. Bil. Ens. Basılmamış Yüksek Lisans Tezi) Elazı̆̆ 2005.

AKPINAR, Birsen, Sivas Fıkraları (Yapı-Isşlev-Bağlam) (G.antep Üni. Sos. Bil. Ens. Basılmamış Yüksek Lisans Tezi) Gaziantep 2007.

ANA BRİTANNICA, “Avcılık”, 3.c., Ana Yayıncılık, 1999, s. 387-394

ARTUN, Erman, Anonim Türk Halk Edebiyatı Nesri, Kitabevi Yayınları, İstanbul 2004.

BAYAT, Fuzuli, "Sosyo-Ekonomik Bağlamda Avcılık Kültü ve Av İyesi”, Folklor/Edebiyat, Sayı: 44, (2005), s. 49-63.

CAFEROĞLU, Ahmet, “Türklerde Av Kültürü ve Müessesesi”, VII. Türk Tarih Kongresi, Türk Tarih Kurumu Basımevi, Ankara 1972, s. 169-174.

ÇELİK, Ali, "Tarih Araştırmalarında Sözlü Kaynakların Önemi ve Fıkralardan Tarihi Öğrenmek", Millî Folklor, Yıl:13, Sayı: 52, (2001), s. 79-86.

EKER, Gülin vd., Halkbiliminde Kuramlar ve Yaklaşımlar, Milli Folklor Yayını, Ankara 2003.

1 Kaynak kişiler, soyadlarına göre alfabetik olarak sıralanmıştır.

Kaynak kişiler hakkındaki bilgiler: Kaynak kişi kodu, adı, soyadı, doğum yeri, doğum tarihi, eğitim durumu, nereden öğrendiği, mesleği. 


\section{Bingöl ARAŞTIRMALARI DERGisi}

EKİĊ, Metin, Halk Bilgisi (Folklor) Derleme ve İnceleme Yöntemleri, Geleneksel Yayınları, Ankara 2004.

ELÇİN, Şükrü, Türkiye Türkçesinde Mâniler, Türk Kültürünü Araştırma Enstitüsü Yayınları, Ankara 1990.

ERGİN, Muharrem, Türk Dil Bilgisi, Bayrak Yay, İstanbul 1998.

HUȘ, Savni, Av Hayvanları ve Avcılık, İstanbul Üniversitesi Orman Fakültesi Yayınları, İstanbul 1974.

INAN, Abdülkadir, Tarihte ve Bugün Şamanizm, Türk Tarih Kurumu Yayınları, Ankara 2000.

KAFESOĞLU, İbrahim, Türk Milli Kültürü, Ötüken Neşriyat, İstanbul 1982.

ÖZBAY, Erhan, Elazığ Yöresi Avcılık Terimleri Sözlüğü, (F. Üni. Sos. Bil. Ens. Basılmamış Yüksek Lisans Tezi) Elazığ 2006.

ÖZBAY, Güven, "Türk Kültüründe Avcılığın Temel Dayanakları", Acta Turcica, Yıl: 1, Sayı: 1, (1999), s. 32-49.

TAN, Nail, Folklor (Halkbilimi) Genel Bilgiler, Özal Matbaası, İstanbul 2008.

T.C. Orman Bakanlığı Doğa Koruma ve Milli Parklar Genel Müdürlüğü Türkiye'de Av ve Yaban Hayatı, Ankara 2005.

TÜRKAN, Kadriye, “Azeri Masallarında Av Kültü ve Av Anlayışı,” Millî Folklor, Yıl: 20, Sayı: 80, (2008), s. 70-76.

TÜRKMEN, Fikret, Nasreddin Hoca Latifelerinin Şerhi (Burhaniye Tercümesi), Akademi Kitabevi, İzmir 1999.

YILDIZ, Naciye, Manas Destanı ve Kırgız Kültürü ile Illgili Tespit ve Tahliller, Türk Dil Kurumu Yayınları, Ankara 1995.

YÜCEL, Selami, Tüm Türküler, Alter Yayınları, Ankara 2015. 


\section{Bingöl ARAŞTIRMALARI DERGisi}

\section{Ek - Örnek Metinler}

\section{Bu Kadar da Olmaz ki}

Avcının biri genç avcılara anlatır:

-Ben sizin yaşınızdayken vurduğum bıldırcınların yağını tenekelere doldurup kışın yemeklerde kullanırdım. (K-1)

\section{Kuyruk}

Avcı oğluna ikazda bulunmuştu:

-Ben avcılar kulübünde arkadaşlarla konuşurken fazla atacak olursam, parmağıma bağlayacağım ipliğin ucundan çekersin, ben de anlarım durumu düzeltirim.

Akşam avcl, kulüpte yine yüksek perdeden atmaya başlamıștı:

-Bugün bir tilki vurdum, kuyruğu rahatlıkla on beș arşın gelir, diye söze başlayınca oğlu ipliği çeker.

Avcı anlayıp durumu düzeltmeye çalışır:

-On beş değilse de on iki vardı.

Oğlu yine ipi çekince:

-Belki yedi sekiz de olabilir.

Yine parmağındaki ipliğin çekildiğini fark edince:

-Ama kesinlikle üç arşından az değildi, der.

Fakat oğlu ipliği tekrar çekince dayanamaz ve der ki:

-Ula velet, bu mübarek hayvan kuyruksuz mu dolaşıyordu? (K-1)

\section{Bir Bıldırcin}

Avdan dönen bir avcl, avcılar kulübüne gelip arkadaşlarıyla oturur:

-Bugün doksan dokuz tane bildırcın vurdum, der.

Tabii ki arkadaşları inanmaz. Biri der ki:

-Bari yüz deseydin de düz hesap olsaydı.

Avcı bozulur ama belli etmez:

-Şimdi getirip bir bıldırcın için yalan mı söyleyeyim. (K-1)

\section{Tavşan Geliri}

Halifan'da köylüler aralarında şöyle bir karara bağlanmışlardı. Avcılar, avladıkları her tavşan için köy sandığına on kuruş bağışta bulunacaklardı. Bu karar yürürlüğe hemen koyuldu. Ertesi gün avdan dönen avcı her vurduğu tavşan kar- 
şılığı muhtara makbuz karşılığında on kuruş ödemeye başladı. Köydeki avcılar arasında atıcılığı ile ün yapmış olanı muhtarın karşısına geldiğinde yirmi kuruş uzatırken:

-Muhtar ben iki tavşan vurdum, diye konuştu.

Bu sözleri köyün muzip avcısı da işitmişti. Usulca muhtarın yanına yaklaştı, kulağına doğru eğilip fısıldadı:

-Muhtar bu adam iki değil üç tavşan vurdu. Seni kandırıyor, der.

Muhtar daha ilk günden bu işin böyle tatsız şekle dönüşmesini engellemek için avcının peşinden koştu, çantasını açmak istedi. Avcı bu talep karşısında önce biraz direnmek ister gibi olduysa da sonunda çantasını açmak zorunda kaldı. Muhtar çantanın içine baktığında avcının dürüp sardığı ceketinden başka bir şey olmadığını gördü. (K-2)

\section{Afrika Avcısı}

Afrika'da avcılığın zor olduğunu anlatan bir avcı:

-Bir gün avda bir sivrisinek gördüm, kırlangıç kadardı. Dolaşırken bir çıtaya rastladım. Yanıma geldi, elimi yaladı, sandım iki numara zımpara sürdüler. (K-2)

\section{Palavra}

Karer Bölgesinin en büyük tavşanını vurduğunu iddia eden bir avcı:

-Tavşan tam on kilo geliyordu, bıyıkları ise bizim Pala Cemal'in bıyıklarından daha uzundu. (K-2)

\section{Sekiz Domuz}

Bir avcıya av dönüşünde arkadaşları sormuşlardı:

-Nasıl, bir şeyler vurabildin mi bari?

Avcı lakayt bir şekilde omzunu silkti:

-Ancak bir fișek atabildim.

Arkadaşlarından biri gülümseyerek baktı yüzüne:

-Onu da boşa attın herhalde.

-Hayır, tam sekiz tane...

-Sekiz tane ne?

-Ne olacak? Domuz! Tam sekiz tane domuz vurdum.

Arkadaşları büsbütün şaşırmıştı.

-Bir fişekle sekiz domuz ha?

-Attığım fișek dokuz gülleydi. Bu yüzden biri boşa gitti maalesef. (K-3) 


\section{BINGÖl ARAȘTIRMALARI DERGISi}

\section{Atan Kazaniyor}

İki eski avcı arkadaş buluştuklarında söz hemen avcılığa dönüvermişti. Birisi bir nefeste anlattı:

-Geçen yıl Sancak'ta avdaydım. Çok da acıkmıştım. Bir de baktım ki bir keklik! Hemen tüfeği doğrulttum. İlk atıșta tüylerini yoldum, İkinci atışta içini temizledim, üçüncü atışta pişirdim.

Arkadaşı bıyık altından gülümseyerek:

-O da bir şey mi? Ben geçen yaz Genç'in dağlarında yüksekten uçan bir kuşa ateş ettim. Meğer hayvan yumurtlayıcı imiş. Korkudan yumurtasını bıraktı. Sonra süzülerek yumurta ile birlikte düşmeye başladı. Yolun yarısında yumurtadan yavru çıktı. Yere düşünceye kadar yavru da büyüdü. Uçmaya başlayacaktı ki onu da vurdum. İkisi birden ayağımın dibine düştü. (K-3)

\section{Sinyal Veriyormuş}

İki avcı otomobilleriyle avlanmaya gidiyorlardı. Avcılardan biri köpeğini arabaya almamıştı:

-Benim köpeğim yorulmak bilmeden koşar, demiști.

Kırk kilometre hızla giderken arkadaşı bakmış, köpek arkadan geliyor. Altmış kilometre hıza çıkarmıș, köpek yine geliyor. Yüz kilometreye çıkarmıș hızı. Köpek yine arkada; fakat dili dışarıya çıkmış halde. Köpeğin sahibine:

-Senin köpek çok yoruldu, bak dili bir karış dışarıda. İstersen arabaya alalım, diyecek olmuş.

Köpeğin sahibi gülmüş bu teklif karşısında:

-Ne yorulması Allah aşkına? Bizi sollayacak da onun için sinyal veriyor bizim köpek. (K-3)

\section{Av Bereketi}

Avcı çevresini saran arkadaşların anlatıyordu:

-Babamla ava gitmiştik. Benim köpek bir ara ferma verdi. Baktım iki tilki yan yana duruyor. Önünde durdukları kayaya ateş ettim. Parçalanıp etrafa saçılan taş parçaları iki tilkiyi cansız yere serdi. Heyecanla oraya giderken ayağım kaydı, dereye düştüm. Ceplerime bir anda sürü halinde balıklar doluverdi. O kadar ki, suyun dibine battım. Boğulmamak için yeri tepip suyun yüzüne çıktım. Çıktığımda ceketimin düğmeleri kopup etrafa saçıldı. Bunlardan biri orda uçan kekliği vurup yere düşürdü. İki tilki bir keklik ve cepler dolusu balıkla eve döndüm ben de. (K-4) 


\section{Bingöl ARAŞTIRMALARI DERGisi}

\section{Keskin Nişancı}

Ahmet ve Mehmet bir sabah ava çıkmışlar. Mehmet, Ahmet'e çok keskin bir nişancı olduğunu anlatıyormuş. O sırada Mehmet'in önünden bir kuş kalkmış ve Mehmet arkasından bir otomatik tüfeği boşaltmış. Ama karavana:

-Oğlum niye vuramadın? Hani çok iyi nişancıydın?

Mehmet gülerek:

-Şu Allah'ın hikmetine bak. Kuş öldü; ama hala uçuyor. (K-4)

\section{Kara Bildırcin}

İki avcı ava çıkmışlar. Avları hiç iyi gitmemiş. Dönerken biri ağaçta gördüğü kargaya ateş etmiş:

-Vurdum vurdum bıldırcını, diye sevinmiş.

Diğer avcl:

-Ne bıldırcını be, baksana simsiyah bir karga bu.

-Hayır hayır, bıldırcındır. Ben geçen bunun karısını vurmuştum da üzüntüden karalar giymiș. O yüzden karga gibi görünüyor. (K-4)

\section{Boş Tüfek}

Avcılar kulübünde cemaat toplanmış, konuşuyormuş. Birisi sonradan gelmiş aralarına. Nerden geldiğini sormuşlar. Adam hararetli bir şekilde ördek avından geldiğini söylemiş. Başlamış anlatmaya:

-Ördeğin biri geliyordu; aldım çifteyi elime, attım ve düşürdüm. Baktım biri daha geliyor, onu da vurdum. Baktım bir tane daha, onu da vurdum.

Oradakilerden biri girer araya:

-İyi de tüfeği ne zaman doldurdun?

-Ördekler arka arkaya gelince doldurmaya fırsatım olmadı ki. (K-5)

\section{Ayı Avı}

Avcılar yine av maceralarını anlatırken biri söze atlar:

-Bir gün ormanda avlanırken baktım karşımda bir ayı. Hemen tüfeği doğrulttum, bir sıktım patlamadı. Allah Allah ne oluyor bu tüfeğe dedim. Çevirdim namluyu baktım ki kurşun geliyor. Hemen çevirdim ayıya vurdum. (K-5)

\section{Kutup Ayısı}

Avcı evine gelen misafirlerine eski bir ayı postunu göstererek:

-Bu ayıyı Kığı'da meșeliklerin içinden vurdum. 


\section{BINGÖl ARAȘTIRMALARI DERGISi}

Misafirlerden biri bu palavraya inanmayarak:

-Nasıl olur? Bu kutup ayısıdır, Kiğı'da bulunmaz ki, der.

Avcı gülümser:

-Kardeşim ayı bu. Buranın kutuplar değil de Kiğı ormanı olduğunu nereden bil$\sin ?(\mathbf{K}-5)$

\section{Yaşlı Avcı}

Avcının biri yanındaki genç avcıların birbirlerine anlattıkları av maceralarını dinlerken dayanamaz, altta kalmamak için kendisi de başlar anlatmaya:

-Bir gün üstüme tam üç tane kurt saldırdı. Birini vurdum ama kurşunum bitti. Birinin kafasını dipçikle dağıttım; ama tüfeğim kırıldı. Üçüncüsü beni kovalamaya başladı. Etrafta ağaç mağaç yok. Önüm uçurum, arkam kurt. Derken dar bir köprüye rastladım, hemen daldım. Bir de baktım köprünün yarısı yıkılmış, aşağısı üç yüz metre uçurum. Kurt da üstüme geliyor.

İhtiyar aşka gelip kendini öyle bir zora sokmuş ki, kurtulmanın mümkünü yok. Gençler sormuşlar:

-Eee sonra ne oldu?

İhtiyar:

-Kurt beni yedi, demiş.

-Amcacım amma da attın ha. İşte yaşıyorsun.

İhtiyar titreyen elini ve parmakların göstererek boynunu bükmüş:

-Buna da yaşamak mı denir gençler. (K-6)

\section{Acemi Avcı}

Genç delikanlı babasına artık usta bir avcı olduğunu ve kendi hikâyelerini anlatmak istediğini söylemiş. Babası kabul etmiş. Kulüpte genç avcıya haydi sıra sende demişler. Genç ve bir o kadar da acemi olan avcı başlamış anlatmaya:

-Bir gün elimde sadece tek fişek kaldı. Baktım kocaman bir tavşan karşımda. Nişan aldım, sıktım, gidip baktım tavşanı hem ayağından hem de gözünden vurmuşum.

Avcılar inanmayıp gülmüşler:

-Tek kurşunla hem ayak hem de göz nasıl oluyor yav?

Genç avcının babası durumu düzeltmeye çalışmış:

-O gün ben de ordaydım. Oğlum nişan aldığı sırada tavşan ayağıyla gözünü kaşıyordu. (K-6) 


\section{Bingöl ARAŞTIRMALARI DERGisi}

\section{Atıp Vuramayanlar}

Avcının biri köy kahvesinde anlatır:

-Dün arkadaşlarla domuz avına çıktık. Karşımıza bir domuz çıktı. Mehmet attı, vuramadı. Veli attı, vuramadı. Ben tüfeğimi doğrulttum, nişan aldım, tetiği çektim.

Bu sırada biraz önce adından bahsettiği Mehmet kahveye girmişti. Avcı hiç istifini bozmadan sözünü tamamladı:

-Ben de vuramadım. (K-6)

\section{Acemi Avcılar}

Beş avcı, ava çıkmış. Yolda küçük bir deliğe rastlamışlar. İçlerinden en deneyimli olanı:

-Yatın yere buradan tavşan çıkacak.

Herkes yatmış yere az sonra gerçekten tavşan çıkmış ve vurmuşlar torbaya koymuşlar. Ava devam ederlerken biraz daha büyükçe bir delik görmüşler, yine tecrübeli avcl:

-Yatın yere buradan tilki çıkacak.

Herkes yatmış tilki çıkmış ve vurmuşlar. Ava devam ediyorlar, karşılarına daha büyükçe bir delik çıkmış, yine tecrübeli olan:

-Yatın yere buradan ayı çıkacak.

Yatmışlar, ayı çıkmış ve vurmuşlar. Herkes tecrübelinin her şeyi bildiğine karar vermiş, ne derse yapıyorlarmış. Devam ederlerken karşılarına oldukça büyük bir delik çıkmış ve Tecrübeli avcı:

-Yatın yere.

Herkes yatmış içlerinden biri:

-Buradan ne çıkacak usta?

Tecrübeli düşünmüş:

-Valla çocuklar buradan ne çıkacağını ben de bilmiyorum; ama ne çıkarsa bahtımiza.

Ertesi sabah bütün gazeteler "Tünel çıkışında beş avcı tren altında kalarak can verdi." diye yazıyormuş. (K-7)

\section{Akıllı Ayı}

Avcının biri ormanda ayı ile burun buruna gelmişti. Ayı, karşısındaki avcıya sordu:

-Benden ne istiyorsun? 


\section{BINGÖl ARAȘTIRMALARI DERGISi}

-Havalar soğuduğu için sıcacık bir kürke ihtiyacım var. Ya sen benden ne istiyorsun?

-Güzelce karnımı doyurmak isterdim sadece.

İkisi birlikte ayının inine gitti. Ayı avcıyı tek lokma bırakmadan yedi. Sonra da:

-İkimizin de istediği oldu sanırım. Benim karnım doydu, avcı da bir kürkün içine girmiş oldu, demiş. (K-7)

\section{Bir Onlardan Bir Bizden}

Gökdere Köyü'nde biri toprağa tuz ekmiş. Ektiği tuz bir türlü çıkmamıș. Köylü bu durumu köydeki zeki birine söylemiş. O da sivrisineklerin bırakmadığını ve bu durumdan kurtulmak için sivrisinekleri avlamaları gerektiğini söylemiş. Tüfeklerini alıp sivrisinek avına çıkmışlar. Tarlaya geldiklerinde bir sivrisinek tarla sahibinin alnına konmuş. Bu da karşısındakine ıslıkla işaret ederek alnındaki sivrisineği arkadaşına göstermiş. Arkadaşı tüfeği doğrultmuş, çekmiş tetiği. Adam yere yı̆̆ılınca:

-Kalksana kardeşim yatma zamanı değil, demiş; fakat nafile, arkadaşı kanlar içinde yerde yatıyor. Yapacak bir şey olmadığını anlayınca:

-E sağlık olsun. Av bu, avlamak da var avlanmak da. Bir bizden gittiyse bir de onlardan gitti. (K-7)

\section{Acil Servis}

Gökdere'de iki avcı ava çıkarlar. Yürüme esnasında avcının biri yere düşer ve hareketsiz olarak yatar. Diğer arkadaşı gelir bakar ki, arkadaşı nefes almıyor. Hemen acil servisi arar:

-Arkadaşım öldü, ne yapmalıyım?

-Sakin olun, ben size yardım edebilirim; ama önce arkadaşının öldüğünden emin olmamız lazım, der.

Birkaç saniye sessizlik olur ve bir el silah sesi duyulur. Sonra:

-Tamam, kesin öldü. Şimdi ne yapmalıyım? der. (K-8)

\section{Kimden Yanasın}

İki arkadaş avda geziyorlardı. Biri sordu:

-Tam burada geçen hafta bir ayı gördüm ve vurdum. Sen olsan ne yapardın?

Diğer avcı bozulur bu soruya:

-Tüfeğim yanımdaysa çeker vururdum.

-Olmasa ne yapardın? 


\section{BINGÖl ARAȘTIRMALARI DERGISi}

-Bıçağımı çeker saldırırdım.

-Bıçağın olmasa ne yapardın?

-Taş atardım.

-Ya taş bulamazsan?

-Ağaca çıkardım.

-Ya civarda ağaç olmazsa?

Avcının tepesi atmış artık:

-Ulan bana bak. Sen benden taraf misın, yoksa ayıdan taraf mı? (K-8)

\section{Kuyruk}

Avcl, kulüpte ballandıra ballandıra anlatır:

-Avlanıyordum, baktım bir tilki. Hemen sarıldım tüfeğe, vurdum baktım kuyruğu 1 metre 10 santimdi. Biraz ilerledim, baktım ki bir tilki daha. Yine sarıldım tüfeğe hakladım. Kuyruğunu ölçtüm, 1 metre 80 santim geldi. Derilerini yüzüp çantama attım.

Köşede oturan yaşlı bir amca lafa girdi:

-Dün evde sobaya odun doldurdum, verdim ateşi. Gürül gürül yanmaya başladı. Bizim kedi beș yavrusuyla gelip sobanın yanına yatacak oldu; fakat borular öyle bir çekiyordu ki, bir anda kedi de yavruları da yattıkları yerden havalanıp sobanın içine girdiler ve bacanın içinden çıkıp gittiler.

Avcı itiraz etti:

-Amca avla ne ilgisi var bilmem amma, bu olacak şey değil.

Yaşlı adam gülümseyerek:

-Evlat, senin vurduğun tilkilerin kuyruğu o kadar uzun olsun da benim sobanın havası bu kadar iyi olmasın mı? (K-8)

\section{Köpeğin Böylesi}

Üç avcı avda bir mola esnasında tartışırlar. Her biri kendi köpeğinin marifetlerini anlata anlata bitiremez. İş öyle büyür ki, neredeyse kavgaya tutuşacak olurlar. İçlerinden en yaşlı olanı araya girer.

-Kavgaya gürültüye ne hacet, salın köpeklerinizi ormana göstersinler marifetlerini.

Avcılar köpeklerini ormana salarlar. İlkinin köpeği, ağzında çok önceden ölmüş bir kekliğin iskeletiyle döner. İkinci köpek bir keklik heykeliyle döner. Üçüncü avcının köpeği ise paçasından yakaladığı bir adamı çeke çeke getirir. Avcılar adamı köpeğin elinden kurtararak: 


\section{Bingöl ARAŞTIRMALARI DERGisi}

-Sen kimsin? diye sorarlar.

Adam nefes nefese:

-“Ben Ahmet KEKLİK, der. (K-9)

\section{Zeki Köpek}

Yine bir sohbette avcılar karşılıklı olarak köpeklerini övüyorlarmıș. Birincisi demiş ki:

-Benim köpeğim çok akıllıdır. Bakkala gönderirim, ne istersem alıp getirir.

Hemen ikinci avcı atlamıș:

-Benim köpeğim istediklerimi almakla kalmaz, paramın üstünü de doğru getirir. Bu sırada üçüncü avcı kendinden emin bir tavırla:

-Sizin köpeklerinizin alışveriş yaptığı dükkânı benim köpeğim çalıştırıyor. (K-9)

\section{Domuz Avı}

Bir Gökdereli ile bir Çiçekdereli ava çıkmışlar. Derken karşılarında bir domuz görmüşler. Gökdereli sıkmış, vuramamış. Çiçekdereli sıkmış, o da vuramamış. Sonra Çiçekdereli oturup acı sonu beklemiş. Gökdereli ise botlarını çıkarıp spor ayakkabılarını giymiş. Çiçekdereli:

-Ne o, domuzdan hızlı mı koşacaksın?

-Yoo, senden hızlı koșsam yeter, demiș. (K-9)

\section{Bacaklarımdan Tanıyın}

Avcılar aralarına yeni katılan avcıyı sınamak isterler ve ellerinde bulunan; av kuşları ile ilgili kitabı çıkartıp bir sayfa açarlar. Bu sayfada bulunan kuşun gövdesini kapatıp bacaklarını çaylak avcıya gösterirler, cevap alamayınca diğer sayfaya geçerler. Ondan da cevap almazlar ve birkaç resim sonra alaylı bir biçimde:

-Senin iyi bir avcı olman için daha çok çalıșman lazım, derler.

Çaylak avcı mahcup ve üzgün olarak aralarından ayrılırken diğer arkadaşlarından biri:

-Ya, senin adın neydi? diye sorunca çaylak avcı bacaklarını açıp gösterir:

-Hadi bilin bakalım. (K-10)

\section{Aslanla Karşı Karşıya}

Avcı, heyecanlı heyecanlı anlatıyordu:

-Aslanla aramda iki metre mesafe ya vardı ya yoktu. O bana gözlerini dikmiş bakıyordu, ben de ona. Bakışları öfke doluydu. Soluğunu yüzümde hissediyordum. 


\section{Bingöl ARAŞTIRMALARI DERgísi}

Dinleyenlerden biri merakla sordu:

-Eee, peki sonra ne oldu?

Avcı omuz silkti:

-Bir şey olmadı. Aslanı orada bırakıp maymunların olduğu kafesin önüne geçtim. (K-10)

\section{Neden işsiz imiş?}

Bir avcı, iş bulmak için iş ve işçi bulma kurumuna gider. Büroda kayıt yapan memur sorar, avcl cevaplar:

-Adınız?

-Hasan.

-Soyadınız?

-Atar.

-Mesleğiniz?

-Avciyım.

-Ne avlarsinız?

-Timsah, fil, balina...

-Bunları nerede avlarsınız?

-Bingöl'de.

Kayıt memuru hayret içinde başını kaldırıp bakar:

-İyi ama timsah, fil, balina Bingöl'de ne arar?

Avcı boynunu büker:

-İşte ben de bu yüzden işsizim ya...(K-10)

\section{Maaşallah}

Köye yeni gelen biri çok usta avcı olduğunu söyler. Köylüler merak ederler. Ertesi gün hep birlikte ava çıkarlar. Usta avcı olduğunu söyleyen şahıs atar atar vuramaz. Köye dönerken bir ağaçta duran kuşu nasıl olursa vurur. Yanındakiler:

-Maşallah maşallah, ne vurdun?

-İri bir bıldırcın vurdum.

Köylülerden biri dayanamaz:

-Cidden usta avcıymıșsın. Hem bıldırcını ağaca kondurdun hem de kukumav kuşunu bıldırcın diye vurdun, der. (K-11) 


\section{Bingöl ARAŞTIRMALARI DERGisi}

\section{O Zaman İş Başka}

Genç adam kızına talip olduğu baba ile konuşuyordu:

-İçkim yok, kumarım yok. İyi niyetliyim, çalışkanım, bir evim, bir de tarlam var. Askerliğimi de yaptım.

Diyerek kendisini anlatmaya koyuldu. Kızın babasının yüzündeki ifadeden adamın bu işe aklının yattığı anlaşılıyordu. Delikanlı laf arasında avcı olduğunu söyleyince baba birden ayağa kalktı:

-O zaman iş değiști. Hakkında tahkikat yapmam lazım, bakalım doğru mu söylüyorsun? (K-11)

\section{Balık mı Koca mi?}

Balıkçı, nehirde avlayıp getirdiği balıkları mahalle arasında satarken bir kadın pencereden seslenir:

-Balıkların taze midir?

-Tazedir.

-Balıkların yağlı mıdır?

-Yağlıdır.

-Bıyıklı midır?

-Bıyıklıdır.

-Erkek midir, diși midir?

Balıkçı dayanamaz:

-Abla sen balık mı alıyorsun, yoksa koca mı seçiyorsun? (K-12)

\section{Sadık Köpek}

Bir avcl diğerine sorar:

-Köpeğinizi satın almak istiyorum; ama sadık mıdır?

-Hem de fazlasıyla sadıktır. Size bu konuda yüzde yüz garanti veriyorum.

-Nasıl bu kadar emin olabilirsiniz?

-Şimdiye kadar beş defa sattım. Her defasında da geri geldi. (K-12)

\section{Ayı Neden Kayıp Düştü?}

Adamın biri avcı arkadaşına anlatır:

-Bir gün çok yorulmuştum, oturdum. Ayının o sıcak nefesini ensemde hissetmez miyim? Derken ayının ayağı kayıp düştü. Ayının gittiğini sandım oturdum. Ayının sıcak nefesi ensemde... Ayağı kayıp düștü yine. 


\section{BINGÖl ARAȘTIRMALARI DERGISi}

Avcl arkadașı:

-Ayıptır söylemesi ben o olayları yaşasaydım altıma ederdim.

Adam:

-Eeee. Ayının ayağı nasıl kayıp düştü sanıyorsun? (K-13)

\section{Ördek Avı}

Avcının biri köy kahvesinde bir macerasını anlatır:

-Geçen ördek avına gittim. Dolma tüfeğime kırk tane saçma doldurdum. Tesadüfe bak önümden de kırk tane ördek kalktı. Tüfeği doğrulttum, sıktım. Gittim ördekleri almaya, saydım otuz dokuz tane. Şaşırdım kaldım nasıl olur da bir tane eksik olur. Bir de baktım ki, ördek havada saçma peşinde. Ördek kaçıyor, saçma kovalıyor. En son ördek ağacın arkasına saklandı. Saçma gelip ağacın önünde durdu. Ördek baktı ki olacağı yok, kanatlarını açıp teslim oldu. Ben de gidip son ördeği aldım. (K-13)

\section{Avcinın Kurnazı}

Ağanın biri keklik etine hasret kalır. Köyün usta avcılarından birini alıp keklik avına çıkarlar. Usta avcı atar atar; fakat vuramaz. Canı son derece keklik eti çeken ağa, buna pek üzülür:

-Yahu çavuş neden vuramıyorsun?

-"Haklısın ağam; bu sabah tahsildarla karşılaştım. Eğer bir sarı lira borcumu ödemezsem varımı yoğumu haciz edeceğini söyledi. Canım çok sıkıldı bu işe. Nişan alırken hep onun yüzünü görüyorum. Bu yüzden doğru dürüst nişan alamıyorum."

Cebinden bir altın lira çıkaran ağa uzatır:

-Çavuş al bakayım şu lirayı. Bundan sonra da arpacığın üzerindeki tahsildarı indirip oraya keklikleri koy, der. (K-14)

\section{Ben Bile Göremiyorum}

Atmakta yekta olan bir avcı her av dönüşünde türlü türlü hikâyeler anlatır. Bir gün yakın dostlarından biri:

-Ya birader, hep anlatıyorsun. Şu vurduklarından ara sıra bize getir, biz de görelim.

Avcl:

-Kardeş imkânsız vallah; çünkü ben bile göremiyorum, demiş. (K-14) 


\section{Bingöl ARAŞTIRMALARI DERGisi}

\section{Kaz ve Kadı}

İki avcı av dönüşü vurduklarını paylaşırken aralarında anlaşmazlık çıkmış. Biri kaz diğeri ördek vurduğundan bunun taksimi mümkün olmamıș. Sonunda kadı'nın karşısına çıkıp bu işe bir çare bulmasını istemişler. Kadı önce eline aldığı avı avcılara sormuş:

-Bu nedir?

-Kazdir.

-Bu kaz kadıya azdır. İki avcıya bir ördek yeter. Siz de varın bunu paylaşın. (K-15)

\section{Cenaze}

Adamın biri en iyi arkadaşının karısının cenazesine gitmiş. Cenaze merasiminden hemen sonra taziyelerini bildirmek üzere arkadaşının yanına gitmiş. Baş sağlı̆̆ı diledikten sonra:

-Tabutun üzerinde bir olta gördüm. Herhalde eşinle ilgili özel bir anısı vardı? diye sormuş.

Adam da:

-Yooo, cenazeden sonra balığa gidecem de, ona hazırlık yaptım, demiş. (K-15) 
